Filip Škiljan

\title{
VJERSKI PRIJELAZI S PRAVOSLAVLJA NA RIMOKATOLIČKU VJERU IZMEĐU 1941. I 1945. NA PODRUČJU KOTARA POŽEGA
}

\begin{abstract}
Sažetak
Autor $\mathrm{u}$ tekstu na temelju arhivske građe, literature i objavljenih izvora donosi podatke o vjerskim prijelazima pravoslavnih na rimokatoličku vjeru na području Požeškog arhiđakonata između 1941. i 1945. godine. Nakon uvodnog dijela o odnosu Rimokatoličke crkve i Nezavisne Države Hrvatske bavi se statističkim pokazateljima broja prijavljenih prijelaznika na području Požeškog arhiđakonata na temelju poimeničnih popisa iz Nadbiskupskog državnog arhiva. Posebno se bavi skupnim/masovnim vjerskim prijelazima koji su poduzimani tijekom jeseni i zime 1941./1942., a koji su provedeni na područjima župa Skenderovci, Požeške Sesvete, Požega, Jakšić, Pleternica, Požeški Brestovac i Ruševo. U cjelini koja se bavi pojedinačnim vjerskim prijelazima zaključuje kako je pojedinačnih vjerskih prijelaza bilo najviše među nacionalno i vjerski mješovitim brakovima, osobito na području Župe Požega. Usprkos brojki od 4.057 podnositelja molbe za prijelaz, zaključuje na temelju arhivske građe kako je prijelaznika bilo mnogo više, njih oko 9.000, ali kako jedan dio njih nije poimenično popisan.
\end{abstract}

Ključne riječi: Drugi svjetski rat; vjerski prijelazi; Požega; Srbi; pravoslavlje.

\section{Odnos Rimokatoličke crkve i Nezavisne države Hrvatske}

Sveta je Stolica prije Prvoga svjetskog rata imala sklopljene konkordate s Crnom Gorom (1886.) i Srbijom (1914.), ali s obzirom na to da ti ugovori nisu bili primjenjivi na novonastalu državu, nakon vatikanskog priznanja nove države 6. studenog 1919. trebalo je sklopiti novi sporazum kojim bi se regulirala pitanja vjeronauka u školama i crkvama, prava vjerskih škola, stjecanja crkvenih dobara, slobode komuniciranja sa Svetom Stolicom, slobode djelovanja katoličkih organizacija te niz drugih pitanja 
iz vjerskog života. ${ }^{1}$ U Kraljevini SHS živjelo je 1921. godine $48 \%$ pravoslavaca, $39 \%$ katolika i 13\% pripadnika ostalih vjerskih zajednica. Pregovori oko konkordata s Vatikanom potrajali su više od desetljeća, da bi se 1935. postigla suglasnost oko svih detalja, a formirani se ugovor, koji Stojadinovićeva vlada potpisuje 1937., poslao u Skupštinu i Senat na usvajanje. Ali tada, zbog ogorčenog protivljenja SPC-a konkordatu, nastaje duboka politička kriza, možda i najveća između dva rata, i proces ratifikacije obustavlja se.

Inače, zbog nereguliranih odnosa s Vatikanom Rimokatolička je crkva u Kraljevini bila u permanentnom latentnom sukobu s državom, a konkordatskom krizom 1937. odnosi su eskalirali i pretočili se u opći međunacionalni antagonizam koji je, između ostalog, rezultirao i preustrojem države (formiranje Banovine Hrvatske). Zbog povlaštenog položaja Srpske pravoslavne crkve u Kraljevini, znatni su bili i pravoslavni prozelitizam i teritorijalna ekspanzija SPC-a na teritorij gdje otprije nije imala korijena. Gradile su se brojne crkve i osnivale parohije na područjima gdje pravoslavlje nije bilo rašireno, a vjerskih prijelaza s rimokatoličke na pravoslavnu vjeru, prema pismu Alojzija Stepinca Papi, bilo je oko 200.000 (Tomašević, 2010., str. 586). Bilo je katolika koji su prelazili na pravoslavnu vjeru samo da bi mogli poboljšati svoj položaj u društvu, dok je dio njih to činio zbog ponovnog sklapanja crkvenog braka. Povlašten položaj Srpske pravoslavne crkve u Kraljevini ogledao se i u neravnomjernoj podjeli proračunskog novca za crkve i vjerske zajednice. Srpska pravoslavna crkva dobivala je čak dvije trećine državnih subvencija (Akmadža, str. 2).

Slijedom tih okolnosti, Rimokatolička crkva u Kraljevini Jugoslaviji vidjela je u uspostavi NDH postignuće i važnog nacionalnog cilja i svojega povlaštenog statusa. Tako nadbiskup Alojzije Stepinac poslanicom katoličkim svećenicima u NDH od 28. travnja 1941. izražava zadovoljstvo zbog ostvarivanja tog cilja i upućuje poziv na „uzvišeni rad oko čuvanja i unapređenja hrvatske države“. Isto su učinili i splitsko-dalmatinski, krčki te senjski biskup. Neposredno nakon proglašenja NDH, nadbiskup Stepinac posjećuje Slavka Kvaternika, a ubrzo potom i dr. Antu Pavelića (Krišto, 2001., str. 37-39).

1 Nakon dugotrajnih pregovora između Kraljevine SHS, pa potom Kraljevine Jugoslavije i Vatikana, nacrt teksta konkordata prihvatile su i jugoslavenska vlada i Sveta Stolica 1935. godine. Da bi stupio na snagu, konkordat je trebala ratificirati Narodna skupština i Senat Kraljevine Jugoslavije. Međutim u kampanju protiv ratifikacije konkordata krenula je Srpska pravoslavna crkva i drugi protukatolički krugovi. Nadbiskup Stepinac 1935. je posjetio patrijarha Varnavu želeći ublažiti njegov otpor konkordatu. Međutim, Varnava je ustrajao u svojem otporu i u prosincu 1936. tražio je jugoslavensku vladu da odbije konkordat. Prijetio je i da će se Srpska pravoslavna crkva svim sredstvima boriti protiv primjene konkordata optužujući vladu za izdaju Srpske crkve. Srpska pravoslavna crkva nakraju je u srpnju 1937. zaprijetila izopćenjem svima koji bi glasali za konkordat, a sukobi su se prenijeli i na ulice. Narodna skupština ipak je ratificirala konkordat, ali je, nakon što je patrijarh Varnava umro, odustala od ratifikacije pred Senatom, tako da je početkom 1938. vlada izvijestila Srpsku pravoslavnu crkvu da je konkordat stvar prošlosti (Akmadža, Katolička crkva u monarhističkoj Jugoslaviji, na www.alfaportal.hr). 
U okviru svoje ideologije „konačnog rješenja srpskog pitanja“ ustaše su Srpsku pravoslavnu crkvu smatrali nositeljem nacionalnog identiteta Srba u Hrvatskoj, pa su se pravoslavni svećenici našli prvi na udaru ustaških vlasti, kako u pokoljima, tako i prilikom organiziranog prisilnog iseljavanja iz NDH. Za pravoslavne je vjernike pak, s ciljem odnarođivanja i asimilacije, bila planirana konverzija - trebalo ih je prevesti na rimokatoličku, odnosno na grkokatoličku vjeru.

Zakonska odredba (uredba) o prijelazu s jedne vjere na drugu donesena je već 3. svibnja 1941. Tim se zakonom ustaška vlast „postavila“ iznad Rimokatoličke crkve, koja je do tada imala potpunu ingerenciju što se tiče vjerskih poslova, što je vidljivo iz članka u kojem stoji da je za valjanost prijelaza potrebno da stranka koja mijenja vjeru podnese pismenu prijavu „upravnoj vlasti prve molbe“ (kotarskoj oblasti, odnosno gradskom poglavarstvu) o svojoj namjeri i da dobije potvrdu o toj svojoj prijavi (Narodne novine, 4. svibnja 1941.). Rimokatolička crkva nije bila zadovoljna takvim miješanjem države $u$ crkvene poslove. U svojim radovima povjesničar Jure Krišto iznimno jasno pokazuje na koji su se način dopisi i okružnice između Crkve i države razmjenjivale i kako je na pojedine crkvene dopise reagirala država, a na koji je način na državne uredbe reagirala Crkva. ${ }^{2}$ Duhovni stol na zakonsku odredbu od 3. svibnja reagirao je već 8. svibnja 1941. stavom da „pristup u katoličku Crkvu može se dopustiti samo onim osobama, za koje postoji osvjedočenje, da to žele učiniti iskreno i s uvjerenjem o istinitosti naše svete vjere i o njenoj potrebi za spas duše“, a da treba odbijati one „koji bi u Crkvu htjeli ući bez ispravnih motiva tražeći u njoj samo zaštitu svojih materijalnih interesa i egoističkih ciljeva" (Katolički list, 19. svibnja 1941.). Nedugo nakon toga, 27. svibnja, Ministarstvo pravosuđa i bogoštovlja NDH objavljuje dokument pod nazivom Uputa o prijelazu s jedne vjere na drugu (Narodne novine, 27. svibnja 1941.). Ministar Mile Budak u tome dokumentu upućuje kotarske i gradske vlasti da jedino one mogu izdavati potvrde o prijavi za vjerski prijelaz. Nedugo potom, u lipnju, objavljeni su i propisi o primanju u Rimokatoličku crkvu. Ministarstvo pravosuđa i bogoštovlja potom, 14. srpnja, šalje biskupskim ordinarijatima NDH dopis iz kojeg se vidi da ustaše ne žele da na rimokatoličku vjeru prelaze pravoslavni svećenici, učitelji, trgovci, obrtnici i bogati seljaci. U dopisu je također vidljivo da država ne želi da pravoslavno stanovništvo prelazi na grkokatoličku vjeru, a također je sasvim jasno da je država ta koja treba izdati dozvolu za vjerski prijelaz (Krišto, 2001., str. 177-179). Crkva 16. srpnja šalje dopis Ministarstvu pravosuđa i bogoštovlja izražavajući neslaganje s branjenjem prijelaza na grkokatoličku vjeru, a također smatra da bi se prijelazi trebali odobravati i pravoslavnoj inteligenciji (Simić, 1958., str. 63-64). Državno ravnateljstvo za ponovu šalje 30. srpnja 1941. okružnicu u kojoj ponavlja

$\overline{2}$ Sve te uredbe, okružnice, upute i dopise moguće je precizno pratiti u knjizi Krišto, 2001., str. 172-202. 
zahtjev hrvatskih vlasti da pravoslavni ne prelaze na grkokatoličku vjeru osim u slučajevima gdje već postoje grkokatoličke župe. U ovoj se okružnici spominju i potvrde o čestitosti koje mogu izdavati jedino kotarska i općinska poglavarstva, a bez kojih se ne može ni otpočeti postupak vjerskog prijelaza. Te upute vrijedile su za cijelu NDH, osim za područje Krbave i Psata te župe Gore (Đurić, 1991., str. 45-46), dok je iz dopisa koji vrh Crkve upućuje crkvenoj hijerarhiji početom kolovoza 1941. posve jasno da Crkva pristaje na to da državne vlasti izdaju potvrde o čestitosti, čime zapravo prepuštaju državnim vlastima da odlučuju tko je podoban da dobije dozvolu za vjerski prijelaz, a tko to nije (Krišto, 2001., 182-183). U rujnu 1941. Ministarstvo unutarnjih poslova šalje državnim tijelima i biskupskim ordinarijatima okružnicu kojom se požuruju vjerski prijelazi, tj. traži da se ne rade birokratski problem osobama koje žele prijeći s jedne vjeru na drugu (Krišto, 2001., str. 185-186). Početkom listopada 1941. osniva se vjerski odsjek Državnog ravnateljstva za ponovu, na koji država prebacuje sve poslove vezane za vjerske prijelaze. Konačno, svoj precizni službeni stav prema vjerskim prijelazima i miješanju države u taj posao Crkva zauzima zaključkom u deset točaka na biskupskoj konferenciji 17. - 19. studenog 1941. Kao prvo ističe se da se samo Crkva može i mora baviti prijelazima na rimokatoličku vjeru, kao drugo da samo crkvena hijerarhija može postavljati ljude koji će poučavati prijelaznike u vjeri, kao treće da takvi ljudi mogu biti ovisni samo o crkvenim institucijama, kao četvrto da Katolička crkva priznaje samo one prijelaze koji su obavljeni prema crkvenim propisima, kao peto da državne institucije ne smiju poništavati prijelaze koje Crkva provede, kao šesto da episkopat izabire odbor koji će se brinuti o pridržavanju pravila kod prijelaza, kao sedmo da u Crkvu mogu biti primljeni samo oni koji to slobodno traže, kao osmo da obred u koji će prijelaznik prijeći ne može određivati država, kao deveto da će izabrani odbor organizirati tečajeve za one koji propovijedaju potencijalnim prijelaznicima i kao deseto da se prijelaznicima moraju zajamčiti sva građanska prava (Krišto, 2001., str. 194-202). Na taj se način Rimokatolička crkva zaštitila od optužbi za katolički prozelitizam, za poticanje vjernika drugih konfesija na vjerski prijelaz na rimokatoličku vjeru. Masovno prelaženje s pravoslavne na rimokatoličku vjeru završilo je u proljeće 1942., kada je uspostavljena Hrvatska pravoslavna crkva.

\section{Vjerski prijelazi s pravoslavne na rimokatoličku vjeru na požeškom području između 1941. i 1945.}

Na području Kotara Požega, koji je obuhvaćao 13 župa u Požeškom arhiđakonatu, između 1941.i 1945. godine bilo je, uzimajući u obzir broj pravoslavnog žiteljstva koje je živjelo na tome teritoriju, relativno mnogo prijelaza s pravoslavne na rimokatoličku 
vjeru. 1931. godine bilo je 52.920 stanovnika, od čega 13.028 pravoslavnih $(24,61 \%)$ i 39.008 rimokatolika $(73,71 \%)$, a na području grada Požege od 7.125 stanovnika bilo je 865 pravoslavnih (12,14\%) i 5.799 rimokatolika (81,38\%). Molbe za vjerski prijelaz podnošene su župnicima, a župnici su potom preporučivali molbe Nadbiskupskom duhovnom stolu koji je donosio konačnu odluku o tome tko će biti primljen, a tko ne. Prema popisima koji se čuvaju u Hrvatskom državnom arhivu i Nadbiskupskom arhivu u Zagrebu, vidljivo je da je na području manjeg broja župa podnesenih molbi za prijelaz bilo do stotinu (Velika, Vetovo, Stražeman, Buk i Kaptol). Najveći broj molbi za prijelaz podnesen je u Župi Kutjevo, gdje je u 1941. i 1942. godini podnesena 1.121 molba. Nakon te župe, po broju podnesenih molbi za vjerski prijelaz slijedi Župa Požeški Brestovac sa 634 molbe, potom Požega sa 614 molbi, a zatim Ruševo s 515, Jakšić s 315, Požeške Sesvete s 306 molbi i Pleternica s 284 molbe. Više od stotinu molbi za prijelaz bilo je i u Župi Skenderovci (143). Valja istaknuti kako je najveći broj molbi za vjerski prijelaz na području župa Kutjevo, Požeški Brestovac, Požega, Ruševo, Jakšić, Požeške Sesvete, Pleternica i Skenderovci podnesen skupno, odnosno da su čitava sela i zaseoci tražili da prijeđu na rimokatoličku vjeru podnoseći molbe Nadbiskupskom duhovnom stolu preko lokalnih rimokatoličkih župnika. Iz statističkih podataka dobivenih na temelju poimeničnih popisa sačuvanih u urudžbenom zapisniku u Nadbiskupskom državnom arhivu vrlo je jasno vidljivo da je najveći broj molbi za vjerski prijelaz podnesen 1941. i 1942. godine (1.900 molbi podneseno je 1941., a 2.151 molba 1942.). U posljednje tri godine rata podneseno je sveukupno pet molbi, s tim da u posljednjoj godini rata (1945.) nije bila podnesena nijedna. Valja kazati da je najveća frekvencija prijelaza bila upravo u periodu između listopada 1941. i travnja 1942., kada su se gotovo u pravilu podnosile velike kolektivne molbe za vjerski prijelaz. Takva je dinamika logična jer je u travnju 1942. osnovana Hrvatska pravoslavna crkva, pa znatno opada državni interes za vjerske prijelaze. Vrlo su nam slabo sačuvani sumarni podaci za Pakrački arhiđakonat koji su nastali na temelju izvještaja pojedinih rimokatoličkih župnika 1944. Za svega pet od trinaest tadašnjih župa Požeškog arhiđakonata sačuvani su sumarni podaci. Sasvim je očekivano da se brojke prijelaznika iz tih sumarnih popisa ne poklapaju u potpunosti s brojkama prijelaznika do kojih smo došli prebrojavanjem poimeničnih popisa u urudžbenom zapisniku Nadbiskupskog duhovnog stola. Tako smo naprimjer u urudžbenom zapisniku pronašli 634 molbe za Župu Požeški Brestovac, dok ih župnik u Brestovcu navodi 652. Mnogo se bolje podudaraju popisi za Župu Kaptol, gdje smo u poimeničnim popisima pronašli 3 osobe, a i župnik je 1944. godine sumarno naveo 3 osobe. Izrazit je nerazmjer između rezultata koje smo dobili u Župi Skenderovci, gdje župnik 1944. navodi da je na rimokatoličku vjeru s pravoslavne prešlo čak 4.596 osoba, dok su pronađene svega 143 u popisima urudžbenog zapisnika. Taj je nerazmjer lako 
objašnjiv jer su misionari ${ }^{3}$ koji su bili poslani na područje Župe Skenderovci, odnosno na područje parohija Sloboština, Oljasi i Čečavac, tijekom siječnja i veljače 1942. izvršili niz masovnih prijelaza, odnosno prekrstili su čitava sela i parohije, a popisi prekrštenih nisu se sačuvali. O tim vjerskim prijelazima, kojih je po slobodnoj procjeni bilo i do 5.000, skenderovački je župnik u više navrata izvještavao Nadbiskupski duhovni stol. Nerazmjer, doduše mnogo manji i obrnut, javlja se i kod Župe Jakšić, gdje je u urudžbenom zapisniku pronađeno čak 315 imena i prezimena podnositelja molbi za prijelaz s pravoslavne na rimokatoličku vjeru, dok je župnik dao izvještaj o 273 prijelaza. Teoretski, moguće je da neke molbe nisu bile odobrene na Nadbiskupskom duhovnom stolu, pa to objašnjava veći broj molbi nego što je prijelaza. Broj prijelaza u Župi Stražeman također se ne podudara s brojem pronađenih imena i prezimena onih koji su podnijeli molbe. Ondje je bilo, prema urudžbenom zapisniku, sveukupno 59 molbi za prijelaz, dok je, prema zapisu župnika, sveukupan broj prijelaznika bio 105.

Tablica I. Pregled podnesenih molbi za prijelaz s pravoslavne na rimokatoličku vjeru po župama, prema poimeničnim popisima urudžbenog zapisnika Nadbiskupskog duhovnog stola iz Nadbiskupskog arhiva u Zagrebu

\begin{tabular}{|l|c|c|c|c|c|c|}
\hline Župa & 1941. & 1942. & 1943. & 1944. & 1945. & Ukupno \\
\hline Buk & 0 & 0 & 1 & 0 & 0 & 1 \\
\hline Jakšić & 19 & 296 & 0 & 0 & 0 & 315 \\
\hline Kaptol & 2 & 0 & 1 & 0 & 0 & 3 \\
\hline Kutjevo & 1.026 & 95 & 0 & 0 & 0 & 1.121 \\
\hline Pleternica & 92 & 191 & 0 & 1 & 0 & 284 \\
\hline Požeške Sesvete & 17 & 289 & 0 & 0 & 0 & 306 \\
\hline Požega & 533 & 79 & 0 & 2 & 0 & 614 \\
\hline Požeški Brestovac & 59 & 575 & 0 & 0 & 0 & 634 \\
\hline Ruševo & 19 & 496 & 0 & 0 & 0 & 515 \\
\hline Skenderovci & 69 & 74 & 0 & 0 & 0 & 143 \\
\hline Stražeman & 45 & 14 & 0 & 0 & 0 & 59 \\
\hline Velika & 19 & 0 & 0 & 0 & 0 & 19 \\
\hline Vetovo & 0 & 43 & 0 & 0 & 0 & 43 \\
\hline Ukupno & 1.900 & 2.151 & 2 & 3 & 0 & 4.057 \\
\hline
\end{tabular}

$\overline{3}$ Rimokatolička crkva od samih je početaka djelovala misionarski šireći Isusovo Evanđelje. Kroz povijest mnogi su rimokatolici odlazili u zemlje gdje Evanđelje nije bilo naviješteno. Katolička crkva u svojoj je biti misionarska. Isus je svojim učenicima zapovjedio: „Učinite mojim učenicima sve narode krsteći ih u ime Oca i Sina i Duha Svetoga i učeći ih čuvati sve što sam vam zapovijedio!“ Na taj način širenje rimokatoličke vjere među pravoslavnim žiteljstvom bila je jedna od zadaća Rimokatoličke crkve. Dogmatske razlike između Pravoslavne i Rimokatoličke crkve su: filioque (katolici tvrde da Duh Sveti izlazi i od Oca i od Sina), Papina supremacija, postojanje čistilišta (pravoslavni ne vjeruju u čistilište) te pričešćivanje beskvasnim, a ne kvasnim (običnim) kruhom. 
Tablica II. Sačuvani popis prijelaza s pravoslavlja na rimokatoličku vjeru prema izvještajima župnika iz $1944 .{ }^{4}$

\begin{tabular}{|l|l|}
\hline Župa & $\begin{array}{l}\text { Broj prijelaznika s pravoslavlja na } \\
\text { rimokatoličku vjeru između 1941. i 1944. }\end{array}$ \\
\hline Jaǩšć & 273 \\
\hline Kaptol & 3 \\
\hline Požeški Brestovac & 652 \\
\hline Skenderovci & 4596 \\
\hline Stražeman & 105 \\
\hline
\end{tabular}

Prije podnošenja molbi za vjerski prijelaz trebalo je dobiti potvrdu o čestitosti kod lokalnih kotarskih ili općinskih vlasti, tj. kod lokalnih ustaških logornika ili tabornika. U Hrvatskom državnom arhivu sačuvano nam je relativno mnogo takvih potvrda za Kotar Požega. Ministarstvo pravosuđa i bogoštovlja koristilo se kopijama tih potvrda kao papirom u sekundarne svrhe. Tako su nam na jednoj strani sačuvani podaci o osobama koje traže potvrde, odnosno kojima se potvrda izdaje, a s druge strane zapisi činovnika pisani olovkom tijekom 1943., 1944. i 1945., ali i činovnika koji su pregledavali spomenuti fond nakon Drugoga svjetskog rata. Potvrde su najčešće prerezane na dva dijela, ali su nam sačuvani dijelovi na kojima se vidi identitet osoba koje su tražile potvrdu o čestitosti. Dio dokumenata sačuvan je u izvornom obliku bez sekundarne upotrebe. Radi se, ipak, o manjem broju dokumenata koji su sačuvani na taj način. Prema poimeničnom popisu onih koji su tražili potvrde o čestitosti na području Kotara Požega popisana je 1.731 osoba.

Treći, iznimno vrijedan izvor jest dio fonda Nadbiskupskog duhovnog stola koji nosi naziv Interdijecezalni vjerski odbor (IVO), gdje su nam sačuvani popisi prijelaznika za Župu Ruševo. Kao posebno vrijedan materijal može nam poslužiti i dio fonda Državnog ravnateljstva za ponovu - vjerski odsjek, u kojem nalazimo sumarne podatke o prijelazima, odnosno najavljenim prijelazima za pojedine općine u požeškom kraju.

\section{Skupne molbe za vjerski prijelaz}

Iznimno čest oblik prelaženja s pravoslavne na rimokatoličku vjeru na području Kotara Požega u periodu između 1941. i 1945. bio je skupni prijelaz. Skupni prijelazi nisu bili specifičnost samo požeškoga kraja nego i susjednog područja Nove Gradiške, Novske, Podravske Slatine, Orahovice, Našica, Virovitice, Slavonskog Broda, Pakraca, ali i banijskih kotara (Dvor, Petrinja, Glina, Kostajnica), kotara Moslavine (Bjelovar, Čazma, Kutina, Garešnica) i karlovačkog kraja na području Zagrebačke nadbiskupije. U takvim su molbama čitava sela tražila vjerski prijelaz na

$4 \quad$ NAZ, Nadbiskupski duhovni stol, 2658/1944. 
rimokatoličku vjeru, a popisani su bili svi članovi kućanstva, od najmanjeg djeteta do najstarijih članova.

Najranija molba za kolektivni prijelaz na području Kotara Požega bila je molba sela Ćosinci u Župi Požeške Sesvete, pola pravoslavnog - pola slovačkog naselja, već u svibnju 1941. Svega mjesec i po nakon uspostave NDH, 30. svibnja 1941., došao je župniku u Požeškim Sesvetama Srbin Marko Radišić i najavio odluku cijelog sela da prijeđe na katoličku vjeru. „Ima ih 58 velikih uključeno školska djeca i 13 malih, svega 71 osoba. Razgovori su se, veli, i dogovori o tome medju njima vodili već dulje vremena do ove konačne njihove odluke." Iz dokumenta je vidljivo da župnik nije bio siguran što uraditi. Bio je svjestan da im treba omogućiti prijelaz, ali nije znao bi li to trebalo obaviti skupno ili pojedinačno. Radišića je otpravio kući i preporučio mu da "ne glasaju stvar okolo po selima, nego da se o tom zasad bave samo na tiho medju sobom". Budući da se župnik obratio za savjet Nadbiskupskom duhovnom stolu, dobio je odgovor da se Crkva ne protivi prijelazu, ali da on prijelaz učini „,individualno na taj način da prima redom one koji budu spremni“. Dakako, za takve procedure kasnije više neće biti vremena, ali u to vrijeme, u svibnju 1941., takvo što je još bilo zamislivo. ${ }^{5}$ Iz kasnijih dokumenata vidljivo je da selo Ćosinci u tome trenutku još nije prešlo na rimokatoličku vjeru, već da će se to dogoditi tek sedam mjeseci kasnije.

Druga molba za masovni vjerski prijelaz potječe iz Župe Skenderovci, gdje su stanovnici naselja Bratulji, Brđani i Perenci izrazili želju za prijelaz na rimokatoličku vjeru. Skenderovački župnik Ivo Đanić ističe da se radi o čisto pravoslavnim selima i da "među vjernicima ima i dobrih i zlih, baš kao i medju našima katolicima... Oni su pripravni sagraditi u svakom selu kat. kapelu, gdje bi dolazio svećenik i skupno ih podučavao vjeri kroz dulje vrijeme, te bi istom iza temeljite poduke prešli“. Zanimljiv je komentar župnika kako bi se „između njih (pravoslavnih, op. a.) birali dobri ljudi, a oni koji su nevaljalci te bi Drž. vlast preselila“. Ističe i da su tamošnji pravoslavni vrlo neuki jer su ih „,svećenici zanemarili i ostavili da rastu bez vjerske pouke“. Smatrao je da je najbolji način da se ljudi prime u Rimokatoličku crkvu nakon vjerske pouke te „odabira onih koji su revni“. Kao i sesvetski župnik, ni skenderovački župnik nije znao što mu je činiti, pa mu se činilo najbolje da se obrati Ordinarijatu i da oni odluče da li da ih podučava vjeri ili da „digne ruke od njih“, kako doslovno piše. „Moje je mišljenje da bi se djeca mogla lijepo odgojiti u kat. duhu u školama, te bi danas sutra mogli biti iskreni katolici." Zaključuje da bi trebalo „sagraditi kapele po pravoslavnim selima, probrati najbolje familije, onda ih redovito poučavati, moguće i s misionarima i redovnim svećenicima, pa iza duljeg vremena one koji su revni, tj. koji provode vjerski život: zajednički mole po kućama,

5 NAZ, Nadbiskupski duhovni stol, 5861/1941. 
ne psuju, polaze Svetu Misu, mole krunicu itd. te ih onda primiti“. U odgovoru Nadbiskupskog duhovnog stola vidljivo je koliko je bilo opreznosti u takvim pitanjima. „Kod puka pazite da ih ne povrijedite u njihovoj osjetljivosti i imajte pred očima samo spasenje njihovih duša. Mogli biste si uzeti kroz neko vrijeme i kojeg redovnika..." Posebno je zanimljiv komentar Nadbiskupskog duhovnog stola da se „prijelazi mogu izvršiti, kada molitelji budu spremni, ali u manjim skupinama i bez veće buke ${ }^{\mu .}{ }^{6}$ Iz sačuvanih dokumenata nije vidljivo je li prijelaz tih sela ikada učinjen.

Jedna od relativno ranih molbi za masovni prijelaz na području Kotara Požega potječe s kraja listopada 1941., kada je velik dio sela Crkveni Vrhovci, njih čak 167, tražio preko vjerskog odsjeka Državnog ravnateljstva za ponovu da prijeđu na rimokatoličku vjeru. Taj je prijelaz posebno zanimljiv jer ga je odobrilo Ministarstvo pravosuđa i bogoštovlja. U dopisu stoji doslovno ovako: „Naredjuje se toj Kotarskoj oblasti, da odmah po primitku ovoga riešenja odredi sve potrebno, kako bi imenovana lica, a u sporazumu sa crkvenim vlastima, izvršila što prije zamoljeni i odobreni prielaz. Podjedno u smislu odredbe Predsjedničtva Vlade od 15. rujna 1941. sva ona lica, koja su bilo najavila bilo izvršila vjerski prielaz sa grčko istočne vjere imaju se najustaškije zaštititi, te im se ima osigurati i osobna i imovinska sigurnost i zaštita." Dakle, iz navedenoga se može zaključiti kako Ministarstvo zahtijeva da se selo Crkveni Vrhovci prevede na rimokatoličku vjeru i kako traži od Kotarske oblasti u Požegi da u sporazumu s crkvenim vlastima obavi odobreni prijelaz. Ujedno se iz dopisa doznaje da će oni koji su prešli biti sigurni, odnosno „najustaškije“ zaštićeni, što bi značilo da oni koji ne prijeđu na rimokatoličku vjeru ne mogu imati takvu zaštitu. ${ }^{7}$ Na identičan način prelaze pravoslavci iz sela Ćosine i Vasine Laze te Prnjavor, njih 245, također u Župi Požega, nedaleko od Požege, 21. listopada 1941. ${ }^{8}$, pravoslavci iz sela Škrabutnik, njih 180, pravoslavci iz sela Lipa, njih 24, 189 pravoslavaca iz sela Gradski Vrhovci i Emovački Lug te 46 pravoslavaca iz Vilić Sela ${ }^{9}$ To su rijetki sačuvani dokumenti primjera intervencije Ministarstva pravosuđa i bogoštovlja za vjerski prijelaz stanovništva nekog sela. Takve primjere prelaženja preko Ministarstva pravosuđa i bogoštovlja nalazimo i u Mikleuški pokraj Kutine, pojedinim selima na Baniji u okolici Sunje i u nekoliko sela u okolici Slunja (Kordunski Ljeskovac). Interesantno je da su državne vlasti, odnosno župan Velike župe Livac Zapolje, pitale požeškog svećenika i još neke svećenike što misle o masovnom prijelazu sela Laze, Vrhovci i Komušina, na što su im oni odgovorili da su „radi pouke sigurniji pojedinačni prijelazi nego ovako

\footnotetext{
6 NAZ, Nadbiskupski duhovni stol, 7150/1941.

7 NAZ, Nadbiskupski duhovni stol, 18933/1941.

8 HDA, Ministarstvo pravosuđa i bogoštovlja, Odjel bogoštovlja, kutija 17, 5458-B-1941.

9 HDA, Državno ravnateljstvo za ponovu, Vjerski odsjek, kutija 584, 180/1941.
} 
u masi“ jer se može „svakoga pojedinoga individualno poučavati“. Nadbiskupski duhovni stol odgovorio je da nakon pouke prime u krilo rimokatoličke crkve grkoistočne žitelje sela Vrhovci, Laze i Komušina. „Pouka može biti skupna.“ Uputa o biljegovanju bila je da bogatije obitelji treba biljegovati po kućama, a siromašnima treba oprostiti biljegovanje. Nakon prijelaza, Nadbiskupski duhovni stol savjetuje da se uspostavi zasebna župa, ako je to potrebno, a ako nije, da sela mogu potpasti pod župu u Požegi. ${ }^{10}$ Prijelaz u većini spomenutih sela nije obavljen do kraja 1941. Jedino je selo Komušina prešlo na rimokatoličku vjeru 21. prosinca 1941., ${ }^{11}$ dok su ostala sela uslijed nedovoljne pouke požeškog svećenika, koji do njih nije mogao dolaziti zbog kiša i loših puteva, bila predviđena za vjerski prijelaz sljedeće, 1942. godine. Navodno su, prema izvještaju Općine Požega (vanjska), nakon poglavnikova govora prijelaznicima iz Velike župe Baranja, podnositelji molbi s područja Župe Požega počeli požurivati vjerski prijelaz, posebno u spomenutim selima. ${ }^{12}$ Iako ne postoji službeni dokument o prijelazu stanovništva spomenutih sela, gotovo je sigurno da su ta sela prešla na rimokatoličku vjeru sljedeće, 1942. godine, vrlo vjerojatno na samom početku godine.

Jedna od ranijih većih molbi za masovni prijelaz jest ona koju je rimokatolički župnik uputio Nadbiskupskom duhovnom stolu iz Župe Kutjevo u kasnom listopadu 1941. Ondje su kolektivno na rimokatoličanstvo prešli mještani sela Duboka i Gradište, njih 996. Prema izvještaju župnika od 2. studenog 1941., žitelji Gradišta i Duboke „već dva mjeseca su poučavani u rimokatoličkoj vjeri“ od lokalnog kapelana. „Žitelji su prilično dobro poučeni i još se svaki dan poučavaju tako, da će biti do 9. studenog potpuno spremni." Župnik ističe da su spomenuti pravoslavci iz parohije Gradište „uvjereni (su) o istinitosti katoličke crkve i žele biti katolici, te mole prečasni Nadbiskupski duhovni stol da budu primljeni u krilo katoličke crkve“. Župnik je također podnio molbu za preuređenje pravoslavne crkve u Gradištu u rimokatoličku crkvu te dao dozvolu da se prijelaz obavi 9. studenog u lokalnoj školi, a u slučaju nevremena u pravoslavnoj crkvi. Nadbiskupski duhovni stol dao je uputu lokalnom župniku da nakon prijelaza upiše prijelaznike u knjigu prijelaza te da sve one koji žive u konkubinatu, a za koje nema drugih prepreka, vjenča prilikom samog prijelaza. Međutim, upozoreno je da se svako preuređivanje crkve u rimokatoličku "treba obustaviti, jer će o tome biti izdane posebne upute kasnije“ ${ }^{13}$ Malo kasnije, u veljači 1942., isti je župnik zatražio prijelaz za 63 pravoslavca iz sela Tominovci. ${ }^{14}$ Župnik je tražio da se ceremonija prijelaza obavi u tominovačkoj lokalnoj školi jer je

10 NAZ, Nadbiskupski duhovni stol, 17466/1941.

11 HDA, Državno ravnateljstvo za ponovu, Vjerski odsjek, kutija 584, 633/1941.

12 HDA, Državno ravnateljstvo za ponovu, Vjerski odsjek, kutija 584, 634/1941.

13 NAZ, Nadbiskupski duhovni stol, 19035/1941.

14 NAZ, Nadbiskupski duhovni stol, 2078/1942. 
kapelica za takvo što bila premalena. ${ }^{15}$ Iz dokumenta koji nam je sačuvan u fondu vjerskog odsjeka Državnog ravnateljstva za ponovu vidljivo je da je na području Općine Bekteže bilo 3.350 pravoslavnih žitelja, od kojih je do 15. studenog 1941. na katoličku vjeru prešlo njih 1.577. Među njima su bili i prijelaznici iz Gradišta i Duboke. ${ }^{16}$

U prosincu 1941. župnik iz Požeških Sesveta Đuro Stehna zatražio je kolektivan prijelaz za sve pravoslavne vjernike iz sela Granje, Ćosinci i Trapari. Župnik ističe kako je cijelo selo u pet navrata podučavao glavnim istinama vjere, posebno ispovijedi i pričesti. „Uputio sam ih u sve razlike temeljem historije.“ Župnik također ističe da je išao k pravoslavcima u Granje i Trapare isključivo na njihov zahtjev, a ne na vlastitu inicijativu. Prijelaz je obavljen u siječnju 1942. (iz sela Trapari 51, iz Novoselaca (Ćosinci) 101 i iz Granja 140). Prilikom opisa samog prijelaza župnik ističe da su pravoslavci naučili molitve i krunicu te kako su se mnogi ispovjedili Gospi Lurdskoj u Požeškim Sesvetama prilikom proštenja. Navodno su prijelaz napravili uz opasku: „kamo sreće da smo to prije učinili. To je, vele, način kako se širi sloga. “17 Opis samog prijelaza dao je Petar Šimić iz Granja još za vrijeme rata u izbjeglištvu u Srbiji pred Komesarijatom za izbeglice i preseljenike: „Pred katolički Božić došao je u naše selo Granje opštinski pisar Mato Pavlović i popisivao po kućama sve Srbe odrasle i decu u svrhu pokrštavanja. Na spisku na kome je stajalo da su upisani voljni pokrstiti se da bi izbjegli odlazak u logor, svaki od uvedenih potpisao se. Nepismene je pak sam pisar potpisivao. Tako je ostalo do pred katolička Sveta Tri Kralja. Na dan Sv. Tri Kralja seoski knez Franjo Koler pozvao je pojedinačno po kućama sve odrasle Srbe iz Granja u kuću Luke Grubešića iz Granja. Svi su se odazvali i bilo ih je oko 500 do 600. Ovamo je došao rimokatolički župnik iz Sesveta, opština Kutjevo, po imenu Đuso, prezimena mu ne znam, stari je to čovek bio. On nam je odmah po dolasku objasnio da to nije pokrštavanje, već običan prijelaz, da se ljudi zaštite od ubijanja i odvođenja u logor, i dodao da ne udare na njega za slučaj da se nešto prekrene, jer da on svemu nije kriv. Potom je zapalio dve sveće i nas pozvao da dignemo tri prsta i za njim govorimo nekakovu molitvu na našem jeziku. Razabrao sam da smo izgovorili vjerovanje rimokatoličko. Tom prilikom nije bilo pričesti, niti ispovesti, i sa ovim se prijelaz svršio“" (Đurić, 1991., str. 180).

Nešto kasnije započeli su prijelazi na području Skenderovaca. Početkom prosinca župnik iz Skenderovaca traži prijelaz za 13 pravoslavnih kuća u naselju Lipa pokraj Skenderovaca. Ističe kako je naselje nacionalno mješovito te zahtijeva od Nadbiskupskog duhovnog stola da mu odobri prijelaz za 36 osoba. ${ }^{18}$ Župnik iz

\footnotetext{
15 NAZ, Nadbiskupski duhovni stol, 104-IVO-1942.

16 HDA, Državno ravnateljstvo za ponovu, Vjerski odsjek, kutija 584.

17 NAZ, Nadbiskupski duhovni stol, 1098/1942.

18 NAZ, Nadbiskupski duhovni stol, 21274/1941.
} 
Skenderovaca 7. siječnja 1942. traži stanovitu odštetu za podučavanje prijelaznika u selu Lipa, njih oko 40. Selo se nalazilo pet kilometara od Skenderovaca, pa se župniku činilo da je zaslužio odštetu za pješačenje. ${ }^{19}$ Tri dana kasnije, 10. siječnja 1942., isti je župnik zatražio dozvolu za prijelaz 18 obitelji iz Vilić Sela. Nedugo nakon toga, 13. siječnja, dobio je afirmativan odgovor Nadbiskupskog duhovnog stola. ${ }^{20} \mathrm{Zbog}$ velikog područja s mnogo pravoslavnih žitelja koje je trebala pokriti njegova župa, župnik iz Skenderovaca obratio se Nadbiskupskom duhovnom stolu te je tražio da mu se pošalju najmanje trojica misionara, s obzirom na to da u župi „živi 4.000 žitelja grkoistočne vjere i oni svi žele prijelaz“. ${ }^{21}$ Kako mu Nadbiskupski duhovni stol misionare nije odmah poslao, šalje on 26. siječnja 1942. panični brzojav: „Neka misionari odmah dođu! “22. Nadbiskupski duhovni stol na taj panični brzojav vrlo je brzo reagirao, pa su bila poslana dva misionara, Šantić i Ćuić ${ }^{23}$, ali župnik već 3. veljače 1942. od Nadbiskupskog duhovnog stola traži dozvolu da i on sam prevodi pravoslavne u selima Deževci, Brđani, Perenci, Svrzigaće i Skenderovci. ${ }^{24}$ Bio je nezadovoljan time što nisu odmah poslani i rimokatolički svećenici koji bi preuzeli nove župe, pa je predlagao da se u bivše parohije Sloboština i Čečavac pošalju svećenici koji bi preuzeli tamošnje vjernike. ${ }^{25}$ Iz kasnijih dokumenata vidljivo je da rimokatolički svećenici nisu namješteni na tom širokom prostoru. „Sa prelazom grko-istočnjaka ova je župa uvećana za 5.000 duša. Kako sam čuo, župnika neće moći dobiti. Ko će se brinuti oko duhovnog napretka toga naroda, ja ne znam." Skenderovački župnik tada je zamolio za to da on i lokalni kapelan Vjenceslav Skuhala služe misu u školama i pravoslavnoj crkvi u Sloboštini te da crkvu u Sloboštini blagoslovi, odnosno na taj način pretvori u rimokatoličku. Osim toga ističe vrlo zanimljivu činjenicu. Naime, misionari, iako su prekrstili većinu pravoslavnog stanovništva na tome području, nisu na rimokatoličku vjeru željeli prevesti starce koji nisu mogli dolaziti na pouke. Župnik doslovno kaže da će „iste smatrati, da su in periculo mortis (dakle, u smrtnoj opasnosti)“ i da će prema tome postupiti, što bi značilo da će ih sam bez dozvole Nadbiskupskog duhovnog stola prevoditi na rimokatoličku vjeru. Misionari su većinu prijelaznika primili u Rimokatoličku crkvu bez ispovijedi i svete pričesti jer su smatrali da su tamošnji pravoslavci „toliko zaostali, da nijesu kadri razumjeti svete tajne, pa da ih svetogrdno ne prime, nijesu ih pripustili na sv.

19 NAZ, Nadbiskupski duhovni stol, 56-IVO-1942.

20 NAZ, Nadbiskupski duhovni stol, 1040/1942.

21 NAZ, Nadbiskupski duhovni stol, 55-IVO-1942.

22 NAZ, Nadbiskupski duhovni stol, 100-IVO-1942.

23 Čini se da su, osim ova dva misionara pri prijelazu pravoslavnih vjernika na katoličku vjeru na tom području pomagali i skenderovački kapelan Skuhala i rimokatolički svećenik iz Požege Beluhan (NAZ, Nadbiskupski duhovni stol, 186-IVO-1942.).

24 NAZ, Nadbiskupski duhovni stol, 100-IVO-1942.

25 NAZ, Nadbiskupski duhovni stol, 100-IVO-1942. 
ispovijed“ ${ }^{26}$ Budući da su novi rimokatolici, nekadašnji pravoslavci, na području nekadašnjih parohija u Čečavcu, Oljasima i Sloboštini potpali pod skenderovačkog župnika, župnik je zahtijevao da im se nametne luknarsko podavanje, jer ondje ima i starih katolika koji bi se, ako se nove katolike oslobodi plaćanja svećeničkih podavanja, našli u podređenom položaju. ${ }^{27}$ Za župnika u Sloboštini skenedrovački župnik Ivo Đanić predlagao je Slovenca Vjekoslava Skuhala. Očito je da to nije bilo uobičajeno jer se Đanić ispričava Nadbiskupskom duhovnom stolu kako „nema svećenika Hrvata, pa bi Skuhala bio jedini podoban za to mjesto“. Osim toga, Đanić je predložio da sjedište nove župe u Sloboštini bude smješteno u Skenderovcima, ,jer se u sela te župe zalijeću četnici od kojih bi mogao stradati (župnik, op. a.)“. To znači da su već početkom 1942. partizanski upadi u sela na zapadu Požeške kotline s Papuka i Psunja bili tako učestali da nije bilo preporučljivo da se župnik ondje nastani. ${ }^{28}$

U Općini Ruševo stanje je bilo slično. Radilo se o brdskom kraju, gdje su pojedina sela zbog loših vremenskih prilika tijekom kasne jeseni i zime 1941./1942. od svojeg općinskog središta bila gotovo odsječena. U Općini Ruševo već se tijekom listopada 1941. godine prijavilo čak 856 osoba za vjerski prijelaz, a tijekom studenog 1941. još njih 8, ali ih nije imao tko prevesti na rimokatoličku vjeru dok nije došao vjeroučitelj Grščić. ${ }^{29}$ Prijelaz je obavljen tek u veljači 1942. U dijelu fonda Nadbiskupskog duhovnog stola pod nazivom Interdijecezalni vjerski odsjek nailazimo na vrlo zanimljiv izvještaj koji je očito napisao poslani misionar, „vjeroučitelj” Grščić, koji je imao zadatak podučavati pravoslavce na području Župe Ruševo prije prijelaza na rimokatoličku vjeru. Prve je poduke vjeroučitelj Ante Grščić davao u selu Latinovac, a njegove su poduke za muškarce i žene trajale deset dana. U selo Latinovac Grščić je stigao 9. veljače 1942. i ondje je svakodnevno držao tečaj u mjesnoj školi između 9, 30 i 12,30 h za muškarce, a poslijepodne između 14 i 16,30 za žene. „Iza toga vježbao sam mladež naše najpoznatije crkvene pjesme, koje su dosta lijepo pjevali na sam dan svojeg prijelaza." Od 18,30 h dolazili su mu na poduku radnici koji su preko dana bili zaposleni na željeznici. Svetu misu Grščić je držao ujutro u pravoslavnoj crkvi „koju sam prije blagoslovio“. Priznaje da su ljudi na misu dolazili „iz kurioznosti“. Grščić tvrdi da su pravoslavci polazili poduku redovito i da su, kada je došlo do velikih snježnih nanosa, jedino manjkale starije osobe koje su stanovale u obližnjim

26 NAZ, Nadbiskupski duhovni stol, 152-IVO-1942.

27 NAZ, Nadbiskupski duhovni stol, 152- IVO-1942.

28 NAZ, Nadbiskupski duhovni stol, 185-IVO-1942. Župa u Sloboštini trebala je obuhvaćati sela Sloboština, Kujnik, Pasikovci, Crljenci, Posreće, Vranić, Nježić, Klisa, Smoljanovci, Ozdakovci, Mrtovlasi, Milivojevci, Bratulji, Oljasi, Svrzigaće, Rasna, Koprivna, Džigerovci, Čečavac, Šnjegavić, Vučjak, Ruševac i Dragutinovac. Za sva ta sela skenderovački župnik ističe kako su nastanjena prijelaznicima, kojih je 5.000.

29 HDA, Državno ravnateljstvo za ponovu, Vjerski odsjek, kutija 584, 542/1941. 
Ivanovcima. Grščić citira starije muškarce i žene koji su ga molili da ih ne prisiljava da znaju sve istine Rimokatoličke crkve: „Gospodine pustite me, vjerujem sve što i vi, ali stara glava ne može to držati ili Gospodine, već sam 45 godina star, pa nikad nisam znao ni svoju bogomolju (Oče naš), pa teško onda ide vaše..." Vjeroučitelj Grščić bio je uistinu vrijedan u svojem radu. Tako je, usprkos strašnim mećavama koje su zadesile taj kraj sredinom veljače, želio dobiti dozvolu Nadbiskupskog duhovnog stola za 426 prijelaza, oprost od donošenja dokumenata i ozova za sedam parova te jednu konvalidaciju braka, pa je do najbližeg telefona u Bektežu pješačio nekoliko kilometara, ali vezu sa Zagrebom nije uspio ostvariti. Prijelaz je, usprkos činjenici da nije stupio u kontakt s Nadbiskupskim duhovnim stolom, uspio uraditi s dvije skupine u lokalnoj pravoslavnoj crkvi. „Poslije prelaza prve skupine služila se sveta misa, te su mnogi muški prelaznici pristupili sv. ispovijedi i sv. pričesti. Tako je isto bila sv. misa i poslije prelaza ženske skupine... Od sv. sakramenata bili su odbijeni oko 7 osoba zbog priležništva, te su primljeni pro foro civili... Bolesnici i nemoćni starci su prelazili po kućama.“ Grščić zaključuje da je narod „dosta dobar i nema odbojnosti prema našoj vjeri“. Predlagao je česte svećeničke posjete, pa makar i glasnike, i dobre knjige. Nahvalio je Grščić pravoslavne, pa kaže kako su „pravoslavci željeli da ih ne ostavim već da budem njihov paroh. Taj narod ne traži ništa drugo, nego svećeničko srce, koje imade razumijevanje prema njihovoj nevolji“. Ono što je Grščić dobro shvatio jest da „,intelektualne poduke slabo ovdje donose koristi, jer više kod ovih ljudi vrijedi, da ga čovjek zgrabi za srce“. Grščić je nešto drugačiju situaciju zatekao u Velikom Bilaču, selu koje naziva "gorštačkim“, a za čije stanovnike ističe da im je „razum otupio zbog pijanstva-rakije“. Ipak, kaže kako je „narod ljubazan i kako su dosta skloni religioznosti“. Zanimljiva je njegova primjedba da „dosta nezgodni položaj prave sami katolici, koji se emancipiraju od njih i sa nepovjerenjem na njih gledaju, mjesto da ih bratski prigrle i još pouče“. Grščić je nakraju zaključio da „poduka treba biti sasvim vjerska, a nikada ne treba isticati nacionalnosti ili nevaljanosti njihovog dosadašnjeg vjerovanja". Također nije dobro obilaziti okolo „s harmonikami i učiti te ljude preporodne pjesme, kako to neki čine, mjesto propovijedanje riječi Božjih" ${ }^{30}$ Osim Velikog Bilača i Latinovca, u Župi Ruševo prešli su i stanovnici sela Imrijevci i Paka. Nakon prijelaza žitelji sela Imrijevci i Paka u župi Ruševo „podastiru brzojavom sinovsku odanost i zahvalnost“ Alojziju Stepincu. ${ }^{31}$ Za razliku od Velikog Bilača, gdje odnosi između pravoslavaca i katolika nisu bili dobri, kako primjećuje Grščić, kao primjer dobrih odnosa između rimokatolika i pravoslavaca treba poslužiti naselje Latinovac. Ondje su ustaške vlasti željele 1942. srušiti pravoslavnu crkvu, međutim žitelji Latinovca rimokato-

\footnotetext{
30 NAZ, Nadbiskupski duhovni stol, 181-IVO-1942.

31 NAZ, Nadbiskupski duhovni stol, 166-IVO-1942.
} 
ličke vjere obratili su se Nadbiskupskom duhovnom stolu želeći spriječiti rušenje pravoslavne bogomolje. Iznijeli su i nekoliko razloga zbog kojih se ta građevina ne bi smjela srušiti. „Naša župa Ruševo daleko je od nas 7 i pol kilometara, te je ova crkva i nama katolicima, kojih ovdje ima $1 / 5$ služila preko 40 godina kod sahrane umrlih." Istaknuli su i to da će pravoslavni stanovnici Latinovca prijeći na rimokatoličku vjeru, pa rimokatolici ističu kako žele da ta crkva postane „zajednička kapela“ i njima i novim rimokatolicima, odnosno bivšim pravoslavcima. Posebno je važna treća točka, u kojoj se vidi zajedništvo pravoslavaca i rimokatolika u tom naselju. „Sa žiteljima grkoistočne vjere živjeli smo od uvijek dobro i u slozi. Oni su i u najlošijim vremenima u prošlosti bili prema nama dobri i korektni u svakom pogledu i nikad nisu naškodili hrvatskim probicima, nego naprotiv činili su uvijek dobro, kad god su to mogli." Molbu su 26. siječnja 1942. potpisali predstavnici sela iz redova rimokatolika Đuro Fabijan i Mihajlo Szabo. Nadbiskupski duhovni stol preporučio je tu molbu Ministarstvu pravosuđa i bogoštovlja i, koliko se čini, molba je imala efekta jer pravoslavna kapela u Latinovcu ipak nije srušena. ${ }^{32}$

Kao i ostalo pravoslavno stanovništvo Požeške kotline, na rimokatoličanstvo masovno prelaze i mještani sela Bolomače, Oblakovac, Gornji Gučani, Donji Gučani, Busnovi i Brestovac. Upravitelj rimokatoličke župe u Požeškom Brestovcu 12. veljače 1942. podnosi skupnu molbu za 550 osoba. Upravitelj župe u Brestovcu piše da „žitelji ovih mjesta iz vlastite pobude i unutarnjeg uvjerenja žele stupiti u kat. crkvu“. Ističe kako ih na taj korak nije nitko prisilio. Preporukama župnika Nadbiskupskom duhovnom stolu prilagane su i potvrde o čestitosti pojedinaca koje je izdavala kotarska vlast u Požegi, a koje su dostavljane na pet adresa: osobi na koju glasi, rimokatoličkom župnom uredu u Požeškom Brestovcu, općinskom poglavarstvu u Požeškom Brestovcu, vjerskom odsjeku Državnog ravnateljstva za ponovu u Zagrebu i Oružničkoj postaji u Vilić Selu. U potvrdama je stajalo da su molitelji „čestiti i ispravni gradjani“. ${ }^{33}$ Brestovački župnik molio je da se prijelaz obavi u školi u Bolomačama jer je do Brestovca daleko, a mnogi prijelaznici nemaju ni adekvatnu odjeću ni obuću. ${ }^{34}$ Brzojavom se nakon prijelaza javljaju Alojziju Stepincu prijelaznici iz Općine Požeški Brestovac: „Na ovaj veliki i za nas povjesni (sic!) dan vraćanja vjeri pradjedova naših u prisustvu našeg narodnog velikog župana Šimunića šaljemo izraze naše duboke odanosti kako vama osobno tako i Svetoj Rimokatoličkoj crkvi moleći vas da vjerujete da smo za Boga, Hrvatsku i Poglavnika uvjek (sic!) Spremni. ${ }^{\text {“35 }}$ Posebno zanimljiv slučaj predstavlja zahtjev bolničkog duhovnika u požeškoj bolnici koji od Nadbiskupskog duhovnog stola traži dozvolu da bolesnike

\footnotetext{
32 NAZ, Nadbiskupski duhovni stol, 168-IVO-1942.

33 NAZ, Nadbiskupski duhovni stol, 2547/1942.

34 NAZ, Nadbiskupski duhovni stol, 131-IVO-1942.

35 NAZ, Nadbiskupski duhovni stol, 157-IVO-1942.
} 
pravoslavne vjere koji su se u tom trenutku našli u bolnici, a potječu s područja župa Skenderovci i Brestovac prevoditi na rimokatoličku vjeru. ${ }^{36}$ On svoju želju za misionarskom dužnošću objašnjava time što misionari koji djeluju na području Oljasa i Sloboštine nemaju dovoljno vremena da provjeravaju u masovnim prijelazima tko se nalazi u selu, a koga nema, pa se onda i one kojih nema u selu prevodi na rimokatoličku vjeru.

Početkom siječnja 1942. obavljen je i masovni vjerski prijelaz na području Župe Jakšić. Župnik iz Jakšića izvijestio je da se ukupno 49 obitelji iz Jakšića i 42 obitelji iz Treštanovaca prijavilo za vjerski prijelaz. „Od državne vlasti dobili su svi odluke za prijelaz, a sada mole naslov, da bi mogli biti primljeni u kat. crkvu." Jakšićki župnik podučavao ih je dva mjeseca istinama svete vjere, pa zato moli Nadbiskupski duhovni stol da dotične primi. Nadbiskupski duhovni stol odgovorio mu je da spomenuti pravoslavci mogu biti primljeni, ali uz prethodno predan precizan popis svih prijelaznika, odnosno konkubinaca koji mogu sklopiti valjani brak i onih konkubinaca koji to ne mogu te vjerski mješovitih brakova. Po svemu sudeći, čini se da nam taj popis prijelaznika nije sačuvan nego da smo upoznati tek s brojem obitelji prijelaznika. ${ }^{37}$ Ipak, nešto malo kasnije, 20. siječnja 1942., obavljen je masovni vjerski prijelaz u Župi Jakšić za koji nam je sačuvan popis, prvo u selima Treštanovci i Tekić, a potom u naseljima Jakšić i Eminovci. U Treštanovcima i Tekiću bila su 63 prijelaznika, ${ }^{38}$ dok je broj prijelaznika u Jakšiću i Eminovcima bio znatno veći. Ondje je župnik iz Jakšića molio za prijelaz 223 osobe, kojima je 31. siječnja 1942. Nadbiskupski duhovni stol potvrdio valjanost prijelaza. ${ }^{39} \mathrm{I}$ u ostalim župama požeškoga kraja bilo je masovnijih prijelaza, ali znatno manje nego u nabrojenim župama. Tako, naprimjer, 17. siječnja 1942. na rimokatoličanstvo prelazi 138 pravoslavaca iz sela Bzenica, Bresnica, Koprivnica Požeška i Pleternica, a na rimokatoličku vjeru prevodi ih pleternički župnik. ${ }^{40}$

Masovni prijelazi bili su očito karakteristični za taj dio Slavonije. Slična je situacija bila i na slatinskom području, u okolici Orahovice, Našica, Slavonskog Broda, Nove Gradiške, Novske i Virovitice. Stanovništvo se na taj način osjećalo zaštićenije i očekivalo je da će biti tretirano kao i većinsko stanovništvo, dakle kao i Hrvati. Međutim, usprkos masovnosti tih prijelaza, Srbi su stradavali u odmazdama koje su, zbog partizanskih akcija, na tim područjima poduzimali ustaše. Treba također reći da je ta masovnost vjerskih prijelaza svoj vrhunac doživjela tijekom kasne jeseni i zime 1941./1942. Nakon uspostave Hrvatske pravoslavne crkve u travnju 1942.,

\footnotetext{
36 NAZ, Nadbiskupski duhovni stol, 132-IVO-1942.

37 NAZ, Nadbiskupski duhovni stol, 669/1942.

38 NAZ, Nadbiskupski duhovni stol, 1527/1942.

39 NAZ, Nadbiskupski duhovni stol, 2001/1942.

40 NAZ, Nadbiskupski duhovni stol, 2093/1942.
} 
masovni prijelazi na području čitave NDH će prestati, pa su nam tako posljednji prijelazi u požeškom arhiđakonatu zabilježeni sredinom veljače 1942.

\section{Pojedinačne molbe za vjerski prijelaz s pravoslavne na rimokatoličku vjeru}

Da bi se mogla podnijeti molba za prijelaz kod lokalnih župnika, bilo je nužno dobiti potvrdu o čestitosti koju su izdavala općinska i kotarska poglavarska, odnosno ustaški tabori i logori. Takve potvrde sačuvane su nam u manjem opsegu u Hrvatskom državnom arhivu u fondu odjela bogoštovlja Ministarstva pravosuđa i bogoštovlja. Potvrde o čestitosti bile su uvijek pisane uniformno, a izgledale su ovako: „U riješenju molbe po zanimanju rođenog godine u mjestu u ___ općini kojom moli dozvolu da može prijeći sa grčko-istočne vjere na rimokatoličku zajedno sa članovima svoje obitelji i to: (nabrajaju se članovi obitelji) obnalazi ovo gradsko poglavarstvo u Požegi temeljem rješenja Ministarstva pravosuđa i bogoštovlja, odjel za bogoštovlje, u Zagrebu od broj a u smislu okružnice Nezavisne Države Hrvatske od 30. srpnja 1941. br. 48468-1941. dozvoliti zatraženi prijelaz. Biljeg od 30 kuna nalijepljen je i propisno poništen na molbi.“

O izdavanju potvrde o čestitosti obavještavalo se podnositelja molbe, rimokatolički župni ured, predstojništvo gradskog redarstva u Požegi i vjerski odsjek Ministarstva pravosuđa i bogoštovlja u Zagrebu. ${ }^{41}$ Zanimljivi su dokumenti koji pokazuju kako je kotarska oblast u Požegi, prije nego što je izdavala potvrde o čestitosti, podnosila upit vjerskom odsjeku Državnog ravnateljstva za ponovu za pojedince koji su se nalazili na popisu sumnjivih osoba. Tako je kotarska oblast u Požegi podnijela upit za Stevana Gojkovića, Dušana Miletića, Milu Milića i Stevu Kovačevića iz sela Donji Gučani koji su podnijeli molbe za prijelaz, a Državno ravnateljstvo za ponovu odobravalo je prijelaz tih osoba bez obzira na činjenicu da su spomenuti ljudi bili popisani među sumnjivima. ${ }^{42}$ Kotarska je oblast, osim što se obraćala Državnom ravnateljstvu za ponovu, pitala i općinska poglavarstva o ponašanju pojedinaca koji su tražili spomenute potvrde. Čini se da se općinska poglavarstva nisu uvijek pozitivno izražavala o potencijalnim prijelaznicima. Tako je vidljivo da se općinsko poglavarstvo u Jakšiću izjasnilo o Anki Lemaić iz Granja kao o „velikoj Srpkinji“ ${ }^{\star 43}$ ili o Angelini Milojević kao osobi kojoj ne bi trebalo dopustiti da prijeđe na rimokatoličku vjeru, jer je „velikosrpkinja“ te da su joj „muž i dvoje djece napustili područje $\mathrm{NDH}^{\prime \prime} .{ }^{44}$ Nakon dobivanja potvrde o čestitosti, pojedinci su podnosili

\footnotetext{
41 Vidi naprimjer HDA, Ministarstvo pravosuđa i bogoštovlja, Odjel bogoštovlja, kutija 31, 2267-B-1942., 3438-B-1942.

42 HDA, Ministarstvo pravosuđa i bogoštovlja, Odjel bogoštovlja, kutija 31, 2671-B-1942, 2673-B-1942.

43 HDA, Državno ravnateljstvo za ponovu, Vjerski odsjek, kutija 584, 173/1941.

44 HDA, Državno ravnateljstvo za ponovu, Vjerski odsjek, kutija 584, 366/1942.
} 
molbe lokalnim rimokatoličkim župnicima, koji bi molbi prilagali svoju preporuke i onda je proslijedili Nadbiskupskom duhovnom stolu. Pojedini bi župnici preporuke pisali jednoobrazno, dok bi drugi davali posebno obrazloženje za svakog pojedinca. Iz molbi i preporuka vidljivo je koji su bili razlozi pojedinaca za vjerski prijelaz, odnosno na koji su način podnosili molbe. Iz preporuka župnika vidljivo je koliko je pojedinim župnicima bilo stalo do pojedinaca.

Prve dvije podnesene molbe za vjerski prijelaz bile su one od 6. svibnja 1941., podnesene u Požeškom Brestovcu i u Požegi, a podnijeli su ih Adam Petrović i Đuka Milaković. ${ }^{45}$ Među prvim molbama bila je i molba za povratak na rimokatoličku vjeru Josipa Selešija iz Požege, kojeg je majka kao dječaka od šest godina prevela na pravoslavnu vjeru, u trenutku kada je i sama prešla. U odgovoru Nadbiskupskog duhovnog stola 15. svibnja 1941. stajalo je da "ima stranka svoju odluku o prijelazu s jedne vjere na drugu da prijavi pismeno nadležnoj upr. oblasti 1. molbe, koja stranci o toj prijavi izdaje potvrdu“. Dakle, zakon od 3. svibnja o prijelazu s jedne na drugu vjeru bio je $\mathrm{u}$ tom trenutku još vrlo svjež, pa je trebalo požeškog župnika upozoriti kakva je procedura u vezi s prijelazom. Župnik je na to pomalo uvrijeđeno odgovorio da se ta dozvola sama po sebi podrazumijeva kada je on već podnio molbu za prijelaz te je dosada Prečasni naslov „suponirao ipak nekakvo znanje kod nas župnika“ ${ }^{46}$ U sličnoj se situaciji našao Ivan Jagodić sa svojom djecom i suprugom Mađaricom. Jagodić je, kada se njegova majka preudala za Srbina, zajedno s njom prešao na pravoslavnu vjeru. Kada se želio vjenčati s rimokatolkinjom Mađaricom u rimokatoličkoj crkvi, pokojni požeški župnik pravio mu je probleme, tako da je Jagodić otišao u pravoslavnu crkvu i ondje se vjenčao te krstio svoje dvije kćeri. Djeca su mu poslana na školovanje k časnim sestrama. Sredinom svibnja 1941. Jagodić je sa ženom i djecom želio prijeći na rimokatoličku vjeru, ali, kako se čini, nije imao dosta novca za sve takse koje je trebalo platiti za prijelaz. Stoga mu je Gradsko poglavarstvo u Požegi izdalo uvjerenje da je „siromah“ pa da mu treba oprostiti plaćanje biljega za prijelaz na rimokatoličku vjeru. ${ }^{47}$ Zanimljiv je slučaj iz Župe Jakšić, gdje je župnik, očito žaleći siromašnu obitelj Karan, umjesto nje uplatio svoj novac za biljege. „Ja od tih ljudi, koji ništa nemaju nisam mogao ništa ubrati, a da bude naslovu udovoljeno, šaljem u tu svrhu moj novac. “48 Danica Lemajić, siromašna kućna pomoćnica rodom iz Klanca u Lici, prešla je na pravoslavlje s trideset i jednom godinom 1936. Požeški župnik ističe kako je Danica bila upravo prisiljena prijeći na pravoslavlje sa svoje dvije male nezakonite djevojčice jer su joj suprugu obećavali namještenje ako ženu prevede. Požeški župnik ističe kako je ona i nakon prijelaza dolazila „u našu crkvu

\footnotetext{
45 NAZ, Nadbiskupski duhovni stol, 4459/1941 i 4455/1941.

46 NAZ, Nadbiskupski duhovni stol, 4576/1941.

47 NAZ, Nadbiskupski duhovni stol, 4742/1941.

48 NAZ, Nadbiskupski duhovni stol, 16710/1941.
} 
dapače jednoć je bila došla, bili se mogla unatoč prelaza ispovijedati, jer da se ona u pravoslavnoj crkvi ne može ni moliti, a kamoli ispovijedati“" ${ }^{49}$ Slučaj iz Pleternice pokazuje kakav su strah osjećali nakon uspostave NDH ljudi koji su prešli za vrijeme Kraljevine Jugoslavije na pravoslavlje nadajući se da će time poboljšati svoj položaj u tadašnjem društvu ili zbog vjere partnera. Pleternički župnik ističe Rezu Janošević, rođenu Kozarić, koja je 9. travnja 1940. prešla na pravoslavlje, a „sada sa suzama u očima se kaje za taj čin". 50 Sličnu poziciju ima i Zora Pavlović, koja je početkom 1941. prešla na pravoslavnu vjeru zbog vjenčanja s Radomirom Pavlovićem, koji se našao u ropstvu nakon kapitulacije Kraljevine Jugoslavije. ${ }^{51}$ Pojedinci su se vjenčali u pravoslavnoj crkvi i dali krstiti svoju djecu u toj crkvi jer ondje gdje su živjeli nadaleko nije bilo rimokatoličke crkve. Kapetan Antun Petiško vjenčao se s učiteljicom Vidom Jovanović u Pirotu, u istočnoj Srbiji, gdje je služio u vojsci. Ondje je dobio dvoje djece, koja su također krštena u pravoslavnoj crkvi jer rimokatoličke, kako sam ističe, nadaleko nije bilo. Sredinom svibnja 1941. moli da se njegov brak konvalidira i da žena s djecom bude primljena u Rimokatoličku crkvu. Ističe kako je u djetinjstvu imao dobar katolički odgoj i da je tijekom polaženja gimnazije bio članom Marijine kongregacije, ali da ga je „služenje po srpskim garnizonima dovelo u ovakav položaj“. ${ }^{2}$ I bogatiji i utjecajniji ljudi prelazili su s pravoslavlja na rimokatoličanstvo. Tako dr. Milorad Breberina iz Požege, sudac kotarskog suda u Požegi, podrijetlom iz Iriga, traži prijelaz za sebe i svog sina, a supruga rimokatolkinja traži odrješenje od cenzure ${ }^{53}$; Sava Maksimović, gostioničar u Požegi, traži pak prijelaz za sebe, suprugu, kćer i unuka. ${ }^{54}$ Bilo je i podnositelja molbi za prijelaz koji su u paničnom strahu za svoju sudbinu i sudbinu svoje djece bili spremni i na rastavu braka ako to bude nužno. Tako su Josip Begovac i Ana Rašperger iz Ciglenika, rimokatolici koji su prešli na pravoslavlje i vjenčali se 1928. u pravoslavnoj crkvi, bili spremni rastaviti se zato da bi tako rastavljeni mogli s djecom prijeći na rimokatoličku vjeru. Kutjevački župnik, koji je taj prijelaz preporučio Nadbiskupskom duhovnom stolu, ističe kako će se Ana Rašperger preseliti iz Ciglenika u Podravsku Slatinu zato da bi pokazala kako se spremna rastaviti od svojeg supruga da bi mogla dobiti odobrenje Nadbiskupskog duhovnog stola za vjerski prijelaz. Čini se ipak da Nadbiskupski duhovni stol nije zahtijevao od Ane Rašperger i Josipa Begovca rastavu. ${ }^{55}$ Stražemanski župnik molio je posebno za one koje su živjeli izvan zakonitog braka. Tako je preporuke pisao za

\footnotetext{
49 NAZ, Nadbiskupski duhovni stol, 4843/1941.

50 NAZ, Nadbiskupski duhovni stol, 4986/1941.

51 NAZ, Nadbiskupski duhovni stol, 7706/1941.

52 NAZ, Nadbiskupski duhovni stol, 5481/1941.

53 NAZ, Nadbiskupski duhovni stol, 7560/1941.

54 NAZ, Nadbiskupski duhovni stol, 7707/1941.

55 NAZ, Nadbiskupski duhovni stol, 6110/1941.
} 
konkubince koji su imali djecu i za konkubince čiji su partneri još uvijek bili živi. Od Nadbiskupskog duhovnog stola tražio je da budu primljeni makar pro foro civili. Nadbiskupski duhovni stol to mu je odobrio, ali im nije dozvolio da prijeđu pro foro ecclesiastico. ${ }^{56}$ Sličan je slučaj bio i s tri para iz okolice Jakšića koji nisu primljeni u Rimokatoličku crkvu sve dok „ne urede svoj odnošaj pred Bogom“ ${ }^{57}$ Za Stevu Protića, Srbina vjenčanog u rimokatoličkoj crkvi svete Barbare, garantirao je jakšićki župnik: „Prema svjedočanstvu mojih župljana Stevo Protić je siromašni imovinski kočijaš, ali inače miran čovjek." Osim toga jakšićki župnik ističe kako je Stevo čitao godinu dana Glasnik Srca Isusovog, pa je svakako dobro upućen u vjerske istine. ${ }^{58} \mathrm{U}$ Župi Požeške Sesvete pojedinci su tražili da im se izda potvrda o tome da su prijavili prijelaz, a takvu potvrdu izdavala im je kotarska oblast. Tako je nakon izdavanja takve potvrde sesvetski župnik tražio Nadbiskupski duhovni stol da dozvoli vjerski prijelaz za obitelji Dejanović i Ivošević. „Budući sam ih poučio u glavnim istinama vjere molim prečasni naslov za dozvolu da ih smijem primiti u katoličku crkvu. Dejanović veli, da u opće nikad nije bio u pravoslavnoj crkvi, isto kao i Jula i Pero Ivošević, nego su uvijek u školi ostajali na vjeronauku. A i mati im Naranča uvijek je služila kod katolika i znade sve molitve i uvijek žive medju katoličkim svijetom. ${ }^{\prime 59}$ Sesvetski župnik bio je dobronamjeran i često je pisao preporuke za Srbe iz okolnih sela. Tako je napisao i molbu za Pavla i Amaliju Bobić iz Ćosinaca i njihovu djecu. Amalija je rimokatolkinja koja je s pravoslavnim Pavlom ušla u brak u pravoslavnoj crkvi. Djeca su im pravoslavne vjere, a župnik predlaže da ih se sve primi u Rimokatoličku crkvu. ${ }^{60}$ Bilo je i prijelaza pravoslavnih Rusa koji su se na područje Požege doselili nakon Oktobarske revolucije. Tako je Vasilije Balandin, rođen u Rusiji 1884., tražio prijelaz za sebe i dva sina, a za suprugu oproštenje od cenzure. ${ }^{61}$ Ponekad su se pojedini spisi na pošti izgubili. Tako se dogodilo da su obitelji Vasić i Mirković tri mjeseca uzaludno čekale rješenje Nadbiskupskog duhovnog stola o svojem prijelazu. Nakon tri mjeseca župnik iz Velike konačno je odlučio zamoliti Nadbiskupski duhovni stol da vidi što je s poslanim dokumentima, na što mu je Nadbiskupski duhovni stol odgovorio da uopće nije primio poslanu molbu, odnosno preporuku, pa neka ponovo pošalje. ${ }^{62}$

Osim pojedinačnih vjerskih prijelaza nekadašnjih rimokatolika i pravoslavaca na rimokatoličku vjeru, postojali su i prijelazi u omanjim skupinama pravoslavaca na rimokatoličku vjeru. Župnik iz Pleternice Franjo Radović popisivao je takve i

\footnotetext{
56 NAZ, Nadbiskupski duhovni stol, 1320/1942.

57 NAZ, Nadbiskupski duhovni stol, 1356/1942.

58 NAZ, Nadbiskupski duhovni stol, 6206/1941.

59 NAZ, Nadbiskupski duhovni stol, 7772/1941.

60 NAZ, Nadbiskupski duhovni stol, 9537/1941.

61 NAZ, Nadbiskupski duhovni stol, 7815/1941.

62 NAZ, Nadbiskupski duhovni stol, 17333/1941.
} 
skupno tražio prijelaz za sve navedene. Na kraju takvih popisa navodio je da su svi "gore spomenuti poučavani istinama kat. vjere, te su izjavili želju, da prijeđu u kat. vjeru, te i posjećuju nedjeljom i službu božju u kat. crkvi““ ${ }^{63} \mathrm{Na}$ području Župe Vetovo nije bilo puno vjerskih prijelaza. Od ukupno 43 molbe za prijelaz, koje su sve podnesene 1942., njih 36 bilo je podneseno istovremeno. Radilo se o molbama nekoliko obitelji koje je preporučio vetovski župnik Vjekoslav Tepeš ističući kao razlog njihovu želju da se „,jjedine s pravom crkvom“ ili ,jer je uvjeren da jedino katolička vjera prava". 64

Iz svih tih molbi jasno je vidljivo da je u to vrijeme bilo mnogo nacionalno i vjerski mješovitih brakova u kojima su se supružnici, zajedno sa svojom djecom, kao pripadnici pravoslavne vjere osjećali neugodno i nesigurno, pa su od državnih i crkvenih vlasti tražili da prijeđu na rimokatoličku vjeru. Crkva nije priječila vjerski prijelaz tim ljudima te im je omogućavala da bez ikakvih problema prijeđu na rimokatoličku vjeru. Kod siromašnih žitelja rimokatolički župnici isticali su njihovo siromaštvo i zalagali se za to da ne plaćaju biljege za prijelaz, a ponekad su i sami plaćali biljege za prijelaznike.

\section{Zaključak}

Iz svega iznesenog moguće je zaključiti da je na području Kotara Požega, na kojem je 1941. godine moglo biti najmanje 14.000 pravoslavaca, veći dio njih prešao, makar formalno, na rimokatoličku vjeru. Iako poimenični popisi koje posjedujemo ne ukazuju na tako velik broj prijelaza, odnosno ukazuju na 4.057 molbi za prijelaz, jasno je vidljivo da je samo na području Župe Skenderovci bilo čak preko 4.400 prijelaza više nego što je poimenično popisano. Sve u svemu, moguće je zaključiti da su se takvi masovni prijelazi koji nisu popisani u dokumentaciji Nadbiskupskog duhovnog stola mogli dogoditi i na području nekih drugih župa u Požeškom arhiđakonatu, iako o tome nemamo pisana traga. Dakle, najmanji broj prijelaznika, odnosno podnositelja molbe za prijelaz s pravoslavne na rimokatoličku vjeru na području Kotara Požega iznosio je 8.500 osoba, što bi značilo da je najmanje $60 \%$ stanovništva pravoslavne vjere na području Kotara Požega željelo prijeći na rimokatoličku vjeru. Ako tome broju pridodamo i podatke iz drugih arhiva, posebno iz fonda Državnog ravnateljstva za ponovu, gdje je popisano još 439 potencijalnih prijelaznika koji nisu zabilježeni u fondu Nadbiskupskog duhovnog stola, broj potencijalnih prijelaznika na području Požeškog arhiđakonata penje se na gotovo 9.000, što je već blizu 2/3 pravoslavnog stanovništva Kotara Požega. Dakako, ne možemo biti sigurni tko je sve od potencijalnih prijelaznika prešao, a za koga su

63 Vidi naprimjer NAZ, Nadbiskupski duhovni stol, 6162/1941. i 6163/1941.

64 NAZ, Nadbiskupski duhovni stol, 1508/1942. 
samo podnesene molbe, iako zapravo nije prešao, ali iz dokumentacije je vidljivo da je Nadbiskupski duhovni stol prihvatio većinu podnesenih molbi, što bi značilo da su oni faktički prešli na drugu vjeru. Tek za masovne molbe iz Državnog ravnateljstva za ponovu ne možemo biti sigurni da su prihvaćene jer o njima, osim za selo Komušinu te sela Crkveni Vrhovci, Ćosine i Vasine Laze, nemamo povratnu informaciju crkvenih vlasti o njihovu prijelazu. Treba također naglasiti da ponekad ne znamo koliki je bio točan broj članova obitelji koji su bili prijavljeni za prijelaz, pa ne možemo sa sigurnošću ustanoviti točan broj potencijalnih prijelaznika s obzirom i na tu okolnost. Treba reći i da vjerski prijelazi nisu pomogli Srbima Požeške kotline da se spase od progona i stradanja. Upravo na području zapadnog dijela Požeške kotline, u selu Sloboština, u kolovozu 1942., dakle oko pola godine nakon vjerskih prijelaza, prema istraživanjima koja su provedena, među 1.368 žrtava, uglavnom izbjeglih Kozarčana smještenih po selima zapadno od Požege, bile su i 203 osobe koje su vukle podrijetlo iz požeškoga kraja. U zaključku ipak treba naglasiti kako su se rimokatolički župnici Požeškog arhiđakonata uglavnom zalagali da pomognu pravoslavnim vjernicima da prijeđu na rimokatoličku vjeru vjerujući da im o tome ovisi materijalna egzistencija te smatrajući, uglavnom pogrešno, da ih na taj način mogu spasiti od progona i stradanja. I župnici koji su prevodili pravoslavne i prijelaznici koji su prelazili na rimokatoličku vjeru griješili su u očekivanjima da će zbog prijelaza biti zaštićeni.

\section{Literatura}

Akmadža, Miroslav. Katolička crkva u monarhističkoj Jugoslaviji na www.alfaportal.hr.

Đurić, Veljko Đ. (1991) Prekrštavanje Srba u Nezavisnoj Državi Hrvatskoj, Prilozi za istoriju verskog genocida, Beograd: Alfa; Arkade.

Krišto, Jure (2001), Sukob simbola: Politika vjere i ideologije u Nezavisnoj Državi Hrvatskoj, Zagreb: Nakladni zavod Globus.

Simić, Sima (1958), Prekrštavanje Srba za vreme Drugog svetskog rata, Titograd: Grafički zavod Titograd.

Tomasevich, Jozo (2010), Rat i revolucija u Jugoslaviji 1941. - 1945., Okupacija i kolaboracija, Zagreb: Europapress holding i Novi liber.

\section{Tiskovine}

Narodne novine

Katolički list 


\title{
Arhivski izvori
}

NAZ (Nadbiskupski arhiv Zagreb), Nadbiskupski duhovni stol

NAZ, Nadbiskupski duhovni stol, IVO (Interdijecezanski vjerski odbor)

HDA (Hrvatski državni arhiv), Državno ravnateljstvo za ponovu, Vjerski odjel

HDA, MPB NDH (Ministarstvo pravosuđa i bogoštovlja NDH), Odjel bogoštovlja

\section{Conversions from the Orthodox to the Roman Catholic Religion in the Period between 1941 and 1945 in the Požega District}

\begin{abstract}
Summary
The author provides information on conversions from the Orthodox to the Roman Catholic and Greek Catholic religions in the Požega Archdeaconry in the period between 1941 and 1945. In the introductory section, the author provides information about the tensions between the Roman Catholic Church and the Serbian Orthodox Church in the Kingdom of Yugoslavia, and the conflict between the Roman Catholic Church and the Independent State of Croatia as a country in the field of religious conversion during the second half of 1941. Following the introduction, the author deals with the statistical data regarding the number of applicants for conversion in the Požega Archdeaconry, based on lists kept at the Episcopal State Archives. The author in particular deals with mass religious conversions that took place during the autumn and winter of 1941/1942, which were conducted in the parishes of Skenderovci, Požeške Sesvete, Požega, Jakšić, Pleternica, Požeški Brestovac, and Ruševo. The third part of the paper deals with individual religious conversions; the conclusion is that the majority of individual religious conversions took place among ethnically and religiously mixed marriages, particularly in the Požega parish.
\end{abstract}

Keywords: World War II; religious conversions; Požega; Serbs; Orthodox religion.

Doc. dr. sc. Filip Škiljan

Institut za migracije i narodnosti

Trg Stjepana Radića 3, 10000 Zagreb

filipskiljan@yahoo.co.uk 